BioLink, Vol. 5 (1) Agustus (2018) p-ISSN: 2356- 458X e-ISSN: 2550-1305

DOI: http://dx.doi.org/10.31289/biolink.v5i1.1689

BioLink

Jurnal Biologi Lingkungan, Industri, Kesehatan

Available online http://ojs.uma.ac.id/index.php/biolink

\title{
DETEKSI BAKTERI GENUS VIBRIO SEBAGAI CAUSATIVE AGENT PADA IKAN LELE SANGKURIANG (Clarias gariepinus var. Sangkuriang) DI KOTA TASIKMALAYA
}

\section{Detection of Genus Vibrio as A Causative Agent on The Sangkuriang Catish (Clarias gariepinus var. Sangkuriang) in Tasikmalaya}

\author{
Vita Meylani*, Rinaldi Rizal Putra \\ Jurusan Pendidikan Biologi FKIP Universitas Siliwangi \\ Jl. Siliwangi No. 24 Tasikmalaya 46115
}

*Corresponding author: E-mail: vibriovita@unsil.ac.id

\begin{abstract}
Abstrak
Ikan Lele Sangkuriang (Clarias gariepinus var. Sangkuriang) merupakan komoditas utama yang banyak dibudidayakan di Kota Tasikmalaya. Akan tetapi pembudidaya mengalami kesulitan karena serangan penyakit yang menyebabkan kematian pada ikan. Kematian yang tinggi diduga merupakan penyakit vibriosis yang disebabkan oleh bakteri genus Vibrio karena terdapat luka kemerahan pada ikan yang mati. Tujuan penelitian ini adalah mengetahui genus Vibrio yang menyebabkan penyakit pada ikan lele Sangkuriang. Sampel diambil dari kolam budidaya Ikan Lele Sangkuriang di Kelurahan Kersanagara Kota Tasikmalaya terdapat 10 ekor yang diduga terserang penyakit vibriosis. Isolasi bakteri dilakukan menggunakan media TCBS. Organ yang diisolasi yaitu luka - luka pada permukaan tubuh, hati, dan ginjal ikan lele. Hasil isolasi diperoleh 21 isolat lalu diseleksi berdasarkan morfologi koloni hingga diperoleh 5 isolat (VK1, VK5, VK7, VK17, dan VK21) kemudian dilakukan uji Postulat Koch. Hasil penelitian menunjukkan bahwa gejala klinis ikan lele yang terserang vibriosis adalah luka kemerahan/borok (ulcer) pada permukaan tubuh, hemoragi (luka kemerahan), perut berisi cairan kuning dan sirip gripis yang disertai luka kemerahan. Identifikasi bakteri dilanjutkan dengan uji biokimia. Deteksi genus Vibrio sebagai penyebab penyakit vibriosis ikan lele Sangkuriang adalah bakteri genus Vibrio (VK 1, VK 5, dan VK 7), Vibrio vulnificus (VK 17 dan VK 21).
\end{abstract}

Kata Kunci : causative agent, Clarias gariepinus var. Sangkuriang, genus Vibrio

\begin{abstract}
Sangkuriang catfish (Clarias gariepinus var Sangkuriang) is the main commodity that widely cultivated in Tasikmalaya City. However, farmers have difficulty because of the disease which causes death in fish. High mortality is suspected as a vibriosis disease by genus Vibrio because redness wounds on dead fish. The purpose of this study is to know the genus Vibrio which causes of disease in Sangkuriang catfish. 10 samples of fish were taken from Sangkuriang catfish pond culture in Kelurahan Kersanagara Tasikmalaya City which were potentially suspected of vibriosis disease. Isolation of bacteria were done on TCBS medium. Bacterial isolates were collected from fish lesion on the body surface, liver, and kidneys of catfish. Isolation were able to gained 21 isolates and then 5 isolates (VK1,VK5, VK7, VK17, and VK21) were selected based on colony morphology and Postulates Koch's were tested. The results showed that the clinical symptoms of catfish infected by vibriosis were redness lesions/ulcers on the body surface, hemorrhagic, fluid inside stomach, and fin eroded with redness wound. Bacterial identification through biochemical test revealed the causative agent of catfish disease at brackish pond area were bacteria of the genus Vibrio (VK 1, VK 5, and VK 7), Vibrio vulnificus (VK 17 and VK 21).
\end{abstract}

Keywords : causative agent, Clarias gariepinus var. Sangkuriang, genus Vibrio

How to Cite: Meylani, V., Putra, R.R (2018), Deteksi Bakteri Genus Vibrio Sebagai Causative Agent Pada Ikan Lele Sangkuriang (Clarias gariepinus var. Sangkuriang) di Kota Tasikmalaya, BioLink, Vol. 5 (1), Hal. 42-50 
Vita Meylani \& Rinaldi Rizal Putra, Deteksi Bakteri Genus Vibrio Sebagai Causative Agent

PENDAHULUAN

Usaha budidaya ikan lele sangkuriang (Clarias gariepinus var Sangkuriang) memiliki prospek yang sangat bagus sehingga memiliki nilai ekonomis yang cukup tinggi di Kota Tasikmalaya. Hal tersebut mendorong budidaya ikan tersebut berkembang pesat di Kota Tasikmalaya. Sentral produksi lele sangkuriang di Kota Tasikmalaya tersebar luas di berbagai wilayah antara lain: Cibeureum, Indihiang, dan Tamansari. Dalam rangka meningkatkan target produksi, pembudidaya melakukan budidaya secara intensif dengan padat penebaran 150-300 ekor $/ \mathrm{m}^{2}$. Akan tetapi, apabila pengelolaannya kurang tepat akan dapat menimbulkan dampak negative terutama adanya serangan penyakit. Serangan penyakit terjadi karena interaksi yang tidak serasi antara tiga komponen utama yaitu lingkungan, biota, dan organisme penyebab penyakit (Irianto, 2005). Penyakit pada ikan lele disebabkan oleh parasit, virus, dan bakteri (Sarjito et al., 2013). Salah satu bakteri yang banyak berasosiasi dengan organisme budidaya adalah genus Vibrio (Austin \& Austin, 2007) dan bertanggungjawab akan vibriosis (Sarjito et al., 2009). Genus vibrio telah banyak dilaporkan menyebabkan penyakit pada ikan diantaranya pada ikan kerapu (Sarjito et al., 2009); ikan mas (Mishra et al., 2010); ikan lele dumbo
(Sarjito et al., 2016) dan mengakibatkan kematian organisme budidaya tersebut (Austin \& Austin, 2007). Jadi, kejadian penyakit pada ikan lele diantaranya dapat disebabkan oleh anggota genus Vibrio.

Genus Vibrio dapat dijumpai di perairan laut dan payau bahkan air tawar dan merupakan bakteri pathogen (Sharma $\&$ Chaturdevi, 2007). Anggota genus Vibrio yang telah banyak dikelan sebagai penyebab penyakit pada ikan diantaranya Vibrio alginolyticus, $V$. damsela, $V$. Charchariae, V. anguilarum, V. ordalli, V. cholera, V. salmonicida, V. vulnificus, $V$. parahaemolyticus, V. pelagia, V. splendida, V. fischeri dan V. harveyi (Austin \& Austin, 2007). Peggy dan Ruth (1996) melaporkan bahwa insidensi bakteri genus Vibrio telah terjadi pada lingkungan muara dan air tawar. Selain itu, Noorlis et al., (2011) melaporkan $V$. alginolyticus menginfeksi ikan kakap merah dan patin, V. fluvialis juga diketahui menyerang ikan mas (Mishra et al., 2010). Hal tersebut menunjukkan bahwa genus Vibrio sebagai penyebab penyakit dapat menyerang berbagai jenis ikan tidak terkecuali lele yang hidup di air tawar. Infeksi yang disebabkan oleh genus Vibrio dapat menyebar dengan cepat terlebih pada kolam budidaya intensif dan mortalitasnya dapat mencapai 100\% (Peggy \& Ryth., 1996). Hal ini menunjukkan keberadaan bakteri ini pada kolam budidaya ikan lele 
BioLink, Vol.5 (1) (2018): hal. 42-50

sangkuriang dapat menurunkan bahkan menghancurkan produksi dan usaha ikan lele sangkuriang.

Penyakit yang diduga disebabkan oleh bakteri ini telah terdeteksi di beberapa kolam budidaya ikan lele sangkuriang di Kota Tasikmalaya. Serangan penyakit ini merupakan permasalahan yang cukup serius bagi pembudidaya, karena berpotensi menimbulkan kematian 50-100\% ikan budidaya dan menurunkan mutu daging ikan.

\section{METODE PENELITIAN}

Metode yang dilakukan pada penelitian ini adalah eksploratif konfirmatory (Nazir, 1999). Sebanyak tiga puluh lima sampel ikan lele sakit diperoleh dari kolam budidaya yang ada di Kota Tasikmalaya. Ikan sampel dipilih secra selektif, dilihat dari gejala klinis yang terlihat mengacu pada Kamiso et al., (1994) dan Sarjito, et al., (2014). Ikan uji berupa benih lele berukuran 7-8 cm diperoleh dari kolam budidaya yang tersebar di Kota Tasikmalaya (Cibeureum, Tamansari, Indihiang).

Isolasi dan purifikasi bakteri dilakukan dengan metode streak pada media TCBS (Sarjito, et al., 2016) di Laboratorium Mikrobiologi FKIP Universitas Siliwangi. Empat puluh dua isolat murni (VK 1-VKT 21) diperoleh dari ginjal, hati dan luka ikan sampel, kemudian disimpan pada media Nutrient Agar Trisalt (NA, Oxoid) miring. Berdasrkan penampakan morfologi (bentuk, warna, dan karakter koloni) dari keempat puluh isolat terpilih 5 isolat (VK1, VK5, VK7, VK17, dan VK21) untuk karakterisasi dan uji Postulat Koch.

Uji Postulat Koch dilakukan di Laboratorium Mikrobiologi, FKIP Universitas Siliwangi. Ketujuh isolat terpilih dikultur pada media cair Zobelt (Sarjito, 2010). Prnyuntikan isolate pada ikan uji dilakukan secara intraperitoneal dengan dosis $0,1 \mathrm{ml}$ dan kepadatan bakteri $10^{8}$ colony forming unit (CFU/ml).

Karakterisasi kelima isolate terpilih dilakukan secara morfologi dan biokimia mengacu pada Macfaddin (1980) dan Sarjito, et al., (2007). Selanjutnya identifikasi bakteri dilakukan berdasarkan Bergeys Manual of Determinative Bacteriology (Holt et al., 1998) dan Bacterial Fish Pathogens: Disease in Formed and Wild Fish (Austin \& Austin., 2007).

\section{HASIL DAN PEMBAHASAN}

Sampel diambil dari berbagai kolam budidaya ikan lele Sangkuriang yang tersebar di berbagai wilayah Kota Tasikmalaya. Sebayak 21 isolat murni 
Vita Meylani \& Rinaldi Rizal Putra, Deteksi Bakteri Genus Vibrio Sebagai Causative Agent

diperoleh dari 10 sampel ikan yang kemerahan, mulut berwarna kemerahan, terdeteksi vibriosis. Gejala klinis vibriosis perut kembung, sirip gripis yang disertai yang tampak pada ikan lele Sangkuriang luka kemerahan pada sirip dada, sirip adalah terdapat lender yang berlebih, luka punggung, sirip ekor, serta hati dan ginjal dibagian kepala, berenang menyendiri, berwarna pucat. Hasil isolasi dari tiga haemorragic, luka kemerahan/ borok puluh lima ikan sampel diperoleh 21 isolat (ulcer) pada permukaan tubuh, sungut bakteri (Tabel 1.)

Tabel 1. Karakteristik isolat berdasarkan penampakan morfologi

\begin{tabular}{cccccc}
\hline No. & $\begin{array}{c}\text { Kode } \\
\text { Isolat }\end{array}$ & $\begin{array}{c}\text { Asal } \\
\text { Isolat }\end{array}$ & $\begin{array}{c}\text { Bentuk } \\
\text { Koloni }\end{array}$ & $\begin{array}{c}\text { Warna pada } \\
\text { TCBS }\end{array}$ & $\begin{array}{c}\text { Karakter } \\
\text { koloni }\end{array}$ \\
\hline 1 & VK 1 & Luka & Bulat & Kuning & Pipih \\
2 & VK 2 & Hati & Bulat & Hijau & Cembung \\
3 & VK 3 & Ginjal & Bulat & Hijau & Cembung \\
4 & VK 4 & Luka & Bulat & Putih & Cembung \\
5 & VK 5 & Luka & Bulat & Coklat & Cembung \\
6 & VK 6 & Ginjal & Bulat & Hijau & Pipih \\
7 & VK 7 & Hati & Bulat & Kuning & Cembung \\
8 & VK 8 & Hati & Bulat & Kuning & Cembung \\
9 & VK 9 & Hati & Bulat & Kuning & Cembung \\
10 & VK 10 & Luka & Bulat & Putih & Cembung \\
11 & VK 11 & Ginjal & Irregular & Putih & Cembung \\
12 & VK 12 & Luka & Bulat & Hijau tua & Cembung \\
13 & VK 13 & Luka & Bulat & Coklat & Cembung \\
14 & VK 14 & Luka & Bulat & Coklat & Pipih \\
15 & VK 15 & Luka & Bulat & Coklat & Cembung \\
16 & VK 16 & Luka & Irregular & Kuning & Cembung \\
17 & VK 17 & Ginjal & Irregular & Putih & Pipih \\
18 & VK 18 & Luka & Bulat & Kuning & Cembung \\
19 & VK 19 & Hati & Bulat & Hijau & Cembung \\
20 & VK 20 & Hati & Bulat & Hijau & Cembung \\
21 & VK 21 & Luka & Irregular & Hitam & Cembung \\
\hline
\end{tabular}

Berdasarkan Karakter Morfologi dipilih 5 isolat yang kemudian diuji (bentuk, warna, koloni) dari 21 isolat, selanjutnya (Tabel 2).

Tabel 2. Tujuh isolat terpilih berdasarkan asal dan penampakan morfologi.

\begin{tabular}{ccccccc}
\hline No. & $\begin{array}{c}\text { Kode } \\
\text { Isolat }\end{array}$ & Media & $\begin{array}{c}\text { Asal } \\
\text { Isolat }\end{array}$ & $\begin{array}{c}\text { Warna } \\
\text { Koloni }\end{array}$ & $\begin{array}{c}\text { Bentuk } \\
\text { Koloni }\end{array}$ & $\begin{array}{c}\text { Karakteristik } \\
\text { Koloni }\end{array}$ \\
\hline 1 & VK 1 & TCBS & Luka & Kuning & Bulat & Pipih \\
2 & VK 5 & TCBS & Luka & Cokelat & Bulat & Cembung \\
3 & VK 7 & TCBS & Hati & Kuning & Bulat & Cembung \\
4 & VK 17 & TCBS & Ginjal & Putih & Irregular & Cembung \\
5 & VK 21 & TCBS & Luka & Hitam & Irregular & Cembung \\
\hline
\end{tabular}

Hasil uji Postulat Koch dari ketujuh isolat terpilih disajikan pada Tabel 3.

Tabel 3. Persentase ikan sakit dan mortalitas ikan uji selama Postulat Koch

No. Kode Jumlah ikan yang menunjukkan Persentase


BioLink, Vol.5 (1) (2018): hal. 42-50

\begin{tabular}{cccc}
\hline & Isolat & gejala klinis (\%) & kematian $(\%)$ \\
\hline 1 & VK 1 & 90 & 90 \\
2 & VK 5 & 90 & 90 \\
3 & VK 7 & 90 & 90 \\
4 & VK 17 & 37 & 37 \\
5 & VK 21 & 100 & 100 \\
\hline
\end{tabular}

Berdasarkan tabel 3, identifikasi secara morfologi dan memperlihatkan bahwa ketujuh isolat biokimia dari ketujuh penyebab penyakit mampu mengakibatkan ikan sakit dan vibriosis pada ikan lele yang kemudian mati berkisar antara 37-100\%. dibudidayakan di berbagai wilayah di Persentase ikan uji yang mennjukkan Kota Tasikmalaya (Tabel 4) adalah (VK 1, gejala klinis atau kematian tertinggi VK 5, dan VK 7), Vibrio vulnificus (VK 17 terdeteksi pada isolat VK 21 (100\%) dan dan VK 21).

terendah pada isolat VK 17 (37\%). Hasil

Tabel 4. Hasil uji morfologi dan biokimia VK 1; VK 5; VK 7; VK 17; dan VK 21

\begin{tabular}{|c|c|c|c|c|c|}
\hline \multirow{3}{*}{ Uji biokimia } & \multicolumn{5}{|c|}{ Kode isolat bakteri } \\
\hline & VK 1 & VK 5 & VK 7 & VK 17 & VK 21 \\
\hline & Vibrio sp. & Vibrio sp. & Vibrio sp. & V. vulnificus & V. vulnificus \\
\hline \multicolumn{6}{|l|}{ Morfologi bentuk } \\
\hline Bentuk koloni & Circular & Circular & Circular & Circular & Circular \\
\hline Bentuk elevasi & Convex & Convex & Convex & Convex & Convex \\
\hline Bentuk tepi & Entrie & Entrie & Entrie & Entrie & Entrie \\
\hline Warna & Kuning & Putih & Putih & Putih & Putih \\
\hline Media/Warna & $\begin{array}{l}\text { TCBS/ } \\
\text { Kuning }\end{array}$ & $\begin{array}{l}\text { TCBS/ } \\
\text { Putih }\end{array}$ & $\begin{array}{l}\text { TCBS/ } \\
\text { Putih }\end{array}$ & TCBS/Putih & TCBS/Putih \\
\hline \multicolumn{6}{|l|}{ Morfologi sel } \\
\hline Gram & - & - & - & - & - \\
\hline Bentuk & Batang & Batang & Batang & Batang & Batang \\
\hline $0 \% \mathrm{NaCl}$ & + & + & + & + & + \\
\hline $5 \% \mathrm{NaCl}$ & + & + & + & + & + \\
\hline \multicolumn{6}{|l|}{$\begin{array}{c}\text { Sifat biologis dan } \\
\text { bikimia }\end{array}$} \\
\hline $0 / \mathrm{F}$ & $\mathrm{F}$ & $\mathrm{F}$ & $\mathrm{F}$ & $\mathrm{F}$ & $\mathrm{F}$ \\
\hline Motility & + & + & + & + & + \\
\hline \multicolumn{6}{|l|}{ Produksi : } \\
\hline Katalase & + & + & + & + & + \\
\hline Oksidase & + & - & - & + & + \\
\hline $\mathrm{H}_{2} \mathrm{~S}$ & - & - & - & - & - \\
\hline Lisin dekarboksilase & + & - & - & $\mathrm{v}$ & V \\
\hline $\begin{array}{c}\text { Ornithine } \\
\text { dekarboksilase }\end{array}$ & - & - & - & - & - \\
\hline TSIA & $\mathrm{K} / \mathrm{K}$ & $\mathrm{A} / \mathrm{K}$ & $\mathrm{A} / \mathrm{K}$ & $\mathrm{A} / \mathrm{A}$ & $\mathrm{A} / \mathrm{A}$ \\
\hline Tumbuh pada $30^{\circ} \mathrm{C}$ & + & + & + & + & + \\
\hline Indol & - & - & - & - & - \\
\hline Metyl-red & + & - & - & + & + \\
\hline Voges-proskaeur & - & - & - & - & - \\
\hline
\end{tabular}


Vita Meylani \& Rinaldi Rizal Putra, Deteksi Bakteri Genus Vibrio Sebagai Causative Agent

\begin{tabular}{cccccc}
\hline \multirow{2}{*}{ Uji biokimia } & \multicolumn{5}{c}{ Kode isolat bakteri } \\
\cline { 2 - 6 } & VK 1 & VK 5 & VK 7 & VK 17 & VK 21 \\
\cline { 2 - 6 } & Vibrio sp. & Vibrio sp. & Vibrio sp. & V. vulnificus & V. vulnificus \\
\hline Simon citrate & - & - & - & + & + \\
Pemecahan gelatin & - & - & - & + & + \\
Urea & - & - & - & - & - \\
Hidrolisis dari: & + & - & - & + & + \\
aesculin & & & & & + \\
\hline Produksi asam dari: & & + & + & + & - \\
\hline Glukosa, acid & - & - & - & - & - \\
Lactose, acid & - & - & - & - & + \\
Sukrosa, acid & - & - & & & + \\
\hline
\end{tabular}

Keterangan :

+: 90\% lebih strain +; -: 90\% strain (-); ND : not determine ; D : 11-89\% (+); V: variabel

Gejala klinis yang terlihat pada ikan ditemukan ulcer pada tubuh ikan sampel. sampel adalah lendir yang berlebihan, Selain itu, pada ikan uji juga ditemukan luka dibagian kepala, berenang perubahan warna tubuh menjadi lebih meyendiri, haemorragic, luka gelap dan terdapat adanya cairan pada kemerahan/borok (ulcer) pada rongga perut/tubuh dan ikan berenang permukaan tubuh, sungut kemerahan, secara tidak beraturan. Austin \& Austin mulut berwarna kemerahan, perut (2007) menjelaskan bahwa gejala klinis kembug, sirip gripis yang disertai luka yang terdeteksi pada ikan sampel dan kemerahan pada sirip dada, sirip ikan uji tersebut mengindikasikan punggung, sirip ekor, serta hati dan ginjal adanya infeksi bakteri genus vibrio. berwarna pucat. Gejala klinis yang sama Gejala klinis yang serupa juga telah pernah dilaporkan oleh Kamso, et al., dilaporkan pada ikan lele di sentral (1994); Red \& Davar (2010); dan Sarjito, produksi Provinsi Jawa Tengah (Sarjito, et al., (2014) pada ikan lele yang et al., 2014). Hasil uji Postulat Koch terserang penyakit bakteri. Gejala klinis diperoleh bahwa ketujuh isolate terpilih tersebut mirip dengan yang dilaporkan mampu mengakibatkan 37-100\% dari oleh Sarjito et al., (2016) pada ikan lele ikan uji sakit dan mati. Hasil penelitian yang diinfeksi oleh anggota genus Vibrio. ini memperlihatkan bahwa ketujuh Hasil pengamatan selama UJi Postulat isolate bakteri tersbut bersifat patogen Koch juga menunjukkan bahwa terdapat terhadap benih ikan lele atau merupakan kemiripan gejala klinis antara ikan uji penyebab penyakit vibriosis pada ikan dengan ikan sampel yaitu borok pada lele Sangkuriang yang tersebar di bekas suntikan, luka kemerahan pada wilayah Kota Tasikmalaya. Oleh karena tubuh, gripis kemerahan di sirip dan itu, temuan ini membuktikan bahwa ujung antenula memerah serta ketujuh isolat tersebut adalah patogen 
sehingga berpotensi sebagai penyebab penyakit vibriosis pada ikan lele Sangkuriang di kolam budidaya yang tersebar di wilayah Kota Tasikmalaya.

Hasil identifikasi secara morfologi dan biokimia menunjukkan bahwa ketujuh isolate merupakan penyebab penyakit vibriosis pada ikan lele Sangkuriang (Clarias gariepinus var. Sangkuriang) yang dibudidayakan di kolam yang tersebar di wilayah Kota Tasikmalaya adalah Vibrio sp. (VK 1, VK 5 dan VK 7) dan Vibrio vulnificus (VK 17 dan VK 21). Bakteri anggota genus Vibrio telah dilaporkan meyebabkan penyakit pada beberapa jenis ikan (Austin, 2011; Red \&Davar, 2010, Randangan, et al., 2012). V. harveyi sebagai penyebab penyakit vibriosis pernah dilaporkan pada berbagai ikan budidaya (Austin \& Austin, 2007; Sarjito et al., 2009; Randangan, et al., 2012). Selain itu anggota genus vibrio dilaporkan sebagai penyebab penyakit juga pernah dilaporkan terjadi pada udang (Tatsuya, et al., 2006; Sarjito, et al., 2012) dan ikan lele (Sarjito, et al., 2014). Selain itu, dilaporkan pula bahwa anggota genus vibrio penyebab vibriosis ditemukan pada ikan kerapu (Sarjito, et al., 2007); udang galah (Mishra, et al., 2010); sidat dan rainbow trout (Tanrikul, 2007). $V$. vulnificus merupakan penyebab penyakit vibriosis pada ikan dan udang yang dibudidayakan di air payau dan laut (Austin \& Austin, 2007). V. logei diisolasi dari ikan sakit (Austin, 2011). V. furnishi ditemukan sebagai penyebab penyakit vibriosis pada ikan (Austin \& Austin, 2007). Insidensi Vibrio sp. pada air tawar telah dilaporkan Noorlis, et al., (2011). Oleh karena itu, penelitian ini memperkuat bahwa anggota genus Vibrio penyebab penyakit pada ikan terutama ikan lele Sangkuriang (Clarias gariepinus var. Sangkuriang.

\section{SIMPULAN}

Hasil penelitian ini menunjukkan adanya gejala klinis ikan lele yang terserang vibriosis adalah luka kemerahan/borok (ulcer) pada permukaan tubuh, hemoragi (luka kemerahan), perut berisi cairan kuning dan sirip gripis yang disertai luka kemerahan. Identifikasi bakteri dilanjutkan dengan uji biokimia. Deteksi genus Vibrio sebagai penyebab penyakit vibriosis ikan lele Sangkuriang adalah bakteri genus Vibrio (VK 1, VK 5, dan VK 7), Vibrio vulnificus (VK 17 dan VK 21). 
Vita Meylani \& Rinaldi Rizal Putra, Deteksi Bakteri Genus Vibrio Sebagai Causative Agent

UCAPAN TERIMAKASIH

Ucapan terimakasih kami sampaikan kepada pihak Ristekdikti yang telah memberikan dana penelitian DRPM tahun 2018 melalui skim Penelitian Dosen Pemula. Selain itu kami sampaikan kepada pihak LP2M-PMP Universitas Siliwangi yang telah memfasilitasi kegiatan hibah ini. Juga kepada Ari Hardian, Asep Yudi Supriatna, Alyaa Nabila, dan Renaldy Rachman yang telah membantu menyelesaikan kegiatan penelitian ini.

\section{DAFTAR PUSTAKA}

Austin B. dan D.A.Austin. (2007). Bacterial Fish Pathogens. Disease in Farmed and Wild Fish. Fourth edition. Ellis Horword limited, Chichester.

Austin, B. (2011). Taxonomy of Bacterial Fish Pathogens. Austin Veterinary Research 2011, 42:20

Holt, J.G., N.R. Kreig, P.H.A. Sneath, J.T. Staley, and S.T. Williams. (1998). Bergey's Manual of Bacteriology

Kamiso H.N., Triyanto dan Sri Hartati. (1994). Karakteristik Aeromonas hydophila pada Ikan Lele (Clarias sp.) Di Daerah Istimewa Yogyakarta Dan Jawa Tengah Selatan. Agric. Sci., $4:$ 741-750.

Mac Faddin, J. F., (1980). Biochemical Test for Identification of Medical Bacteria, Second Edition. Williams \& Wilkins. Baltimore.

Mishra, P., Samanata, Mohanty, Maity. (2010). Characterization of Vibrio Species Isolated From Fesh Water Fishesby Ribotypng. Indian J. Microbiol, 50 (1) : $101-103$

Noorlis, A., Ghazali, F. M., Cheah, Y. K., Tuan Zainazor, T. C., Ponniah, J., Tunung, R., Tang, J. Y. H., Nishibuchi, M., Nakaguchi, Y. and Son, R. (2011). Prevalence and quantification of Vibrio species and Vibrio parahaemolyticus in freshwater fish at hypermarket level. International Food Research Journal, $18: 689-69$.

Peggy A. Reed and Ruth Francis-Floyd. (1996). Vibrio Infections of Fish. University of Florida. Florida.

Rad, M. And Davar.S. (2010). Isolation and Characterization of Vibrio (Listonella) anguillarum from Cat fish. J. Vet. Antm. Sci., 34 (4) : $413-415$.

Randangan., Mohammad L.T., and Ahmed H.A. (2012). Characterization and experimental infection of Vibrio harveyi isolated from diseased Asian seabass (Lates calcarifer). Malaysian Journal of Microbiology, 8(2): . 104-115.

Sarjito, Ningrum, N.E.W., Radjasa, O.K., dan Prayitno, S.B. (2012). Appication of Repetitive Sequence Base PCR on The Richness of Vibrio on The Tiger Shrimps (Penaeus monodon F.) . Jurnal of Coastal Development, 15 (3) : 304-310

Sarjito, Prayitno, S.B. dan Haditomo, A.H.C. (2013). Pengantar Parasit dan Penyakit Ikan. UNDIP Press. Semarang.

Sarjito, Prayitno, S.B., Radjasa O.K dan Hutabarat, S. (2007). Causative Agent Vibriosis pada Kerapu Bebek (Cromileptes Altivelis) dari Karimunjawa 1. Pathogenisitasnya terhadap Ikan Kerapu Macan (Epinephelus fuscoguttatus). Jurnal Ilmu Kelautan, 12(3) : 173-180

Sarjito, Radjasa, O.K., Condro, A.H.C., dan Prayitno, S.B. (2013). Causative Agent Motile Aeromonas Di Sentral Produksi Ikan Lele Provins Jawa Tengah. Disajikan Pada Seminar Nasional KAI - 2013. Solo, 2 - 3 September 2013.

Sarjito, Radjasa O.K, Hutabarat, S dan Prayitno S B. (2009). Phylogenetik Diversity of Causative Agent of Vibriosis Associated with Groupers Fish from Karimunjawa Island, Indonesia. Curr. Res. of Microbiol., $2(1): 14-21$.

Sarjito, Radjasa O.K, Haditomo, Alfabetian. H. Condro, Prayitno S B. (2014). Insidensi Bakteri Genus Vibrio pPada Lele Dumbo (Clarias gariepinus) dari Sentral Produksi Provinsi Jawa Tengah. Seminar Nasional Ke-III Hasil-hasil Penelitian Perikanan 
dan Kelautan Fakultas Perikanan dan Ilmu Kelautan Universitas Diponegoro.

Sarjito, Haditomo, Alfabetian. H. Condro, dan Prayitno S B. (2015). Causative Agent Vibriosis pada Ikan Lele Dumbo (Clarias gariepinus) yang Dibudidayakan di Kolam Beralinitas Rendah. Seminar Nasional KeIV Hasil-hasil Penelitian Perikanan dan Kelautan Fakultas Perikanan dan Ilmu Kelautan Universitas Diponegoro.

Sharma A. and Chaturvedi, A.N. (2007). Population dynamic of Vibrio sp. in the river Narmahada at Jabalpur. J. Enviroment. Biol., $28: 747$ - 751

Sharma, A., C.R., Bora,C.R., Chaurasia, R.K., and Sahu, V. (2009). Antibiotic Suspectibility and Genetic Analysisi of Vibrio species
Isolated from Reverine Enviroent. Curr. Res. Bacteriol., 19: 1 - 13

Sukenda, L. Jamal,D. Wahyuningrum dan A. Hasan. (2008). Penggunaan Kitosan Untuk Pencegahan Infeksi Aeromonas hydrophila Pada Ikan Lele Dumbo Clarias sp. Jurnal Akuakultur Indonesia, 7(2) : 159-169.

Tatsuya N., Emi I., Nakao N., Nobuhiko N., and Masatoshi M. (2006). Comparison of Vibrio harveyi strains isolated from shrimp farms and from culture collection interms of toxicity and antibiotic resistance. Graduate School of Life and Environmental Sciences, University of Tsukuba, Tsukuba, Ibaraki, Japan. 